\title{
Technical Note: An evaluation of 4 clovers and Italian ryegrass for white-tailed deer
}

\author{
MARK K. JOHNSON AND STEPHEN R. SCHULTZ
}

\begin{abstract}
Authors are professor and assistant professor, School of Forestry, Wildlife, and Fisheries, LAES, Louisiana State University Agricultural Center, Baton Rouge, La. 70803.
\end{abstract}

\begin{abstract}
We evaluated winter weight gain of captive male white-tailed deer $(O$ docoileus virginianus) that grazed pastures of berseem (Trifolium alexandrinium L.), white ( $T$. repens $L$.), crimson ( $T$. incarnatum $L_{\text {. }}$, or subterranean ( $T$. subterraneum $L_{\text {.) }}$ clover their first winter and pastures of berceem, white, or crimson clover or Italian ryegrass (Lolium multiflorum Lam.) their second winter. Weight gains the first winter $(14.7 \pm 0.7 \mathrm{~kg})$ did not differ $(P>0.10)$ among the clovers. Bucks that grazed berseem, white, or crimson clover the second winter gained $3.0 \pm 0.5 \mathrm{~kg}$, while bucks that grazed Italian ryegrass gained $0.9 \pm 0.9 \mathrm{~kg}$.
\end{abstract}

Key Words: clover, cool-season forages, Lilium multiflorum, Odocolleus virginianus, Trifolium spp., white-tailed deer

Many clovers and clover mixtures are being promoted by commercial seed companies to enhance rangelands for deer. However, there is little information on potential effects of different clovers on deer growth. The purpose of this study was to compare effects on growth of male white-tailed deer (Odocoileus virginianus)among 4 cool-season clovers.

\section{Materials and Methods}

We studied captive deer at the Louisiana Agricultural Research Station's Ben Hur Farm, East Baton Rouge Parish, La. Levels of soil phosphorus (P), potassium (K), and calcium (Ca) were high. Soil $\mathrm{pH}$ was 6.3. These soils do not require liming or fertilization for good clover production (Peevey 1972).

In late August 1986, 4 deer paddocks (about 0.4 ha each) were roto-tilled. Rhizobium spp. inoculated berseem (Trifolium alexandrinium L.), white ( $T$. repens L.), crimson ( $T$. incarnatum L.), or subterranean ( $T$. subterraneum $L$.) clover seed was broadcast in each paddock on 2 September 1986 . Seeding rates were $15,8,15$, and $15 \mathrm{~kg} / \mathrm{ha}$, respectively. Seed was lightly covered by toothharrowing after broadcasting.

Thirty-three male white-tailed deer fawns were weighed to the nearest pound and randomly assigned to the paddocks on 11 November 1986; 8 fawns to each of the berseem, white, and crimson clover paddocks and 9 to the white clover paddock. Bucks were provided water and feed $(9.0 \%$ crude protein, $1.7 \%$ crude fat, $1.1 \%$ $\mathrm{Ca}, 0.2 \% \mathrm{P}$, and $25.0 \%$ crude fiber) simulating the quality of deer diets on upland pine-hardwood habitats during winter in Louisiana (Causey 1964, Thill and Martin 1980) ad libitum throughout the study. On 10 March 1987, fawns were tranquilized and reweighed to the nearest pound. Bucks grazed pastures of native

\footnotetext{
Funding was provided by the Louisiana Agricultural Experimental Station under Project LABO2516. Sacramento Valley Milling, and Delta and Pineland Seed Companies donated seed. Approved for publication by the Director, Louisiana Agricultural Experiment Station as Manuscript 90-22-4336.
}

grasses and were maintained on water and feed from $10 \mathrm{March}-12$ October 1987.

Paddocks were replanted to the same clovers during September 1987. However, little subterranean clover was available because Italian ryegrass (Lolium multiflorum Lam.) volunteered heavily in that paddock and dominated forage production. Therefore, the paddock intended as a subterranean clover treatment effectively became an Italian ryegrass treatment. Bucks were tranquilized, weighed, and randomly redistributed to the paddocks on 12 October 1987-8 bucks to each of the berseem clover, crimson clover, and ryegrass paddocks and 7 to the white clover paddock. Bucks were maintained as during the first trial and reweighed on 11 April 1988.

Sward conditions were monitored each winter to ensure there was an abundance of each forage at all times such that consumption was not limited. Pearson's correlation coefficient $(r)$ was used to describe the assocation between initial study weight and weight gain during the first winter. Analysis of covariance was used to evaluate differences in deer weight gains among forages each winter. Initial study weight was the covariable. All data presented are means \pm standard errors.

\section{Results and Discussion}

\section{First Winter}

Two bucks (1 each from the berseem and crimson paddocks) died from unknown causes. Weight gains averaged $14.7 \pm 0.7 \mathrm{~kg}$ and were negatively associated with initial study weights $(r=$ $-0.641, P<0.001)$. However, there were no differences $(P>0.10)$ in weight gains attributable to the clover treatments (Table 1). Fawns

Table 1. Body weights and weight gains (kg) of captive male white-tailed deer that grazed different cool-season forages their first (11 Nov. 1986-10 Mar. 1987) and second (12 Oct. 1987-11 Apr. 1988) winters; Ben Hur Biological Research Aren, East Baton Rouge Parish, La.

\begin{tabular}{|c|c|c|c|c|c|c|c|}
\hline \multirow[b]{2}{*}{ Forage } & \multirow[b]{2}{*}{$\mathbf{N}$} & \multicolumn{2}{|c|}{$\begin{array}{l}\text { Initial } \\
\text { weight }\end{array}$} & \multicolumn{2}{|c|}{$\begin{array}{c}\text { Final } \\
\text { weight }\end{array}$} & \multicolumn{2}{|c|}{$\begin{array}{l}\text { Weight } \\
\text { gain }^{1}\end{array}$} \\
\hline & & $\bar{x}$ & SE & $\overline{\bar{x}}$ & $\mathrm{SE}$ & $\overline{\bar{x}}$ & SE \\
\hline & & $\cdots$ & 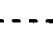 & $\cdots$ & (a) & - & $\cdots$ \\
\hline $\begin{array}{l}\text { First winter } \\
\text { Berceem clover } \\
\text { White clover } \\
\text { Crimson clover } \\
\text { Sub. clover }{ }^{2}\end{array}$ & $\begin{array}{l}7 \\
9 \\
7 \\
8\end{array}$ & $\begin{array}{l}27.4 \\
26.1 \\
22.7 \\
24.6\end{array}$ & $\begin{array}{l}2.4 \\
1.0 \\
2.0 \\
1.9\end{array}$ & $\begin{array}{l}40.1 \\
39.9 \\
40.2 \\
39.8\end{array}$ & $\begin{array}{l}1.9 \\
0.7 \\
2.1 \\
1.3\end{array}$ & $\begin{array}{l}12.7 \\
13.7 \\
17.7 \\
14.9\end{array}$ & $\begin{array}{l}1.1 \mathrm{~A} \\
0.8 \mathrm{~A} \\
0.8 \mathrm{~A} \\
1.8 \mathrm{~A}\end{array}$ \\
\hline $\begin{array}{l}\text { Second winter } \\
\text { Berceem clover } \\
\text { White clover } \\
\text { Crimson clover } \\
\text { Italian ryegrass }\end{array}$ & $\begin{array}{l}8 \\
7 \\
8 \\
8\end{array}$ & $\begin{array}{l}59.1 \\
56.0 \\
54.6 \\
57.6\end{array}$ & $\begin{array}{l}3.0 \\
1.7 \\
2.5 \\
2.3\end{array}$ & $\begin{array}{l}61.1 \\
59.7 \\
57.8 \\
58.5\end{array}$ & $\begin{array}{l}2.6 \\
2.3 \\
2.6 \\
1.8\end{array}$ & $\begin{array}{l}2.0 \\
3.8 \\
3.2 \\
0.9\end{array}$ & $\begin{array}{l}1.0 \mathrm{~A} \\
2.0 \mathrm{~A} \\
1.3 \mathrm{~A} \\
0.9 \mathrm{~B}\end{array}$ \\
\hline
\end{tabular}

IWeight gains each winter followed by different letters are significantly different $(P<0.05)$.

2Subterranean clover. 
that grazed subterranean clover during this 129-day trial gained an average of $117.8 \mathrm{~g} /$ day, consistent with previous studies (Johnson et al. 1985, 1987).

\section{Second Winter}

Weight gains of bucks in the berseem, crimson, and white clover paddocks $(3.0 \pm 0.5 \mathrm{~kg})$ were similar $(P>0.10)$ and greater $(P<0.05)$ than gain of bucks in the ryegrass paddocks $(0.9 \pm 0.9 \mathrm{~kg})$ (Table 1). These results were similar to those of previous studies comparing deer weight gains on clover versus ryegrass (Johnson et al. 1985,1987$)$.

\section{Conclusions}

Our results suggest that many cool-season clovers may produce high winter gains in young male deer, but do not support contentions that 1 type or variety will produce greater body growth than others. Differences in preference by deer among clover species and the practical advantages or disadvantages of utilizing different clovers to enhance deer range should be addressed before recom- mending any clover species or mixture for management application. However, the most effective clovers for supplementing deer nutrition may be those best adapted to soil and climatic conditions in different regions.

\section{Literature Cited}

Causey, M.K. 1964. Nutritional analysis and seasonal variation of some herbaceous deer browse plants in the pine-hardwood areas of Winn and Union Parishes, Louisiana. M.S. Thesis, Louisiana State Univ., Baton Rouge.

Johnson, M.K., S.P. Lynch, and J.A. Zeno. 1985. Effects of supplemental ryegrass versus subterranean clover on fawn weight. Proc. Annu. Conf. Southeast. Assoc. Fish and Wildl. Agencies 39:362-364.

Johnson, M.K., B.W. DeLany, S.P. Lynch, J.A.Zeno, S.R. Schultz, T.W. Keegan, and B.D. Nelson. 1987. Effects of cool-season agronomic forages on white-tailed deer. Wildl. Soc. Bull. 15:330-339.

Peevey, W.J. 1972. Soil test results and their use in making fertilizer and lime recommendations. Louisiana Agr. Exp. Sta. Bull. 600.

Thill, R.E., and A. Martin, Jr. 1980. Seasonal quality of diets selected by tame deer on Louisiana pine-hardwood sites: preliminary findings. p. 19-20. In: The Third Annu. Meeting of the Southeast Deer Study Group. Nacogdoches, Tex. 